\title{
Negativity in Massive Online Open Courses: Impacts on Learning and Teaching and How Instructional Teams May Be Able to Address It
}

\author{
Denise Comer, PhD \\ Assistant Professor of the Practice, Writing Studies \\ Director, First-Year Writing \\ Duke University \\ Ryan Baker, PhD \\ Associate Professor of Cognitive Studies at Teachers College \\ Program Coordinator of Teachers College Masters of Learning Analytics \\ Columbia University \\ Yuan Wang, MA \\ Doctoral Research Fellow in Cognitive and Learning Sciences in Department of \\ Human Development at Teachers College \\ Columbia University \\ There are many positive aspects of teaching and learning in Massive Online Open \\ Courses (MOOCs), for both instructors and students. However, there is also a \\ considerable amount of negativity in MOOCs, emerging from learners on discussion \\ forums and through peer assessment, from disciplinary colleagues and from public \\ discourse around MOOCs. Through mixed-methods case-study research of two \\ diverse MOOCs (one focused on general, introductory-level content and one \\ designed for specialized graduate students and professionals), we consider the \\ following questions: What are the various forms that negativity takes in MOOCs? \\ How might MOOC negativity vary among disciplines? How does negativity impact \\ MOOC instructors and learners? We present evidence suggesting that MOOC \\ negativity poses a serious problem that may be responsible for instructor/ learner \\ disengagement and instructor burnout, and that anticipating and addressing such \\ negativity can improve MOOC learning communities. Lessons learned from these \\ two MOOCs can be beneficial not only to those involved with MOOCs, but also to \\ those involved in other online educational contexts where faculty and learners seek \\ to manage existing and anticipated negativity.
}

MOOCs have great potential for creating new learning opportunities and rich learning experiences for participants through sustained peer-to-peer interaction (Brinton et al., 2013; McAuley, Stewart, Siemens, \& Cormier, 2010). Because they are grounded in networked learning across global contexts, MOOCs make visible the ways in which knowledge can be socially constructed (Gunawardena et al., 2004; Vygotsky, 1978), especially through cross-cultural interaction (Gunawardena, 2007; Kanuka, 2010). They also make content and expert instructors available to a much wider population than has been previously feasible (Comer, 2014; Kolowich, 2013b; Kouzmanoff, 2014). With over 400 universities offering MOOCS, many instructors have also expanded their classrooms to include MOOC content (Shah, 2014), having their students join MOOCs, watch video lectures and complete assignments within the MOOC platform. For these reasons, there has been considerable enthusiasm for MOOCs (Carver \& Harrison, 2013; Daniel, 2012; Weissmann, 2012), even if it is tempered by some concerns about completion rates (Jordan, 2013; Parr, 2013; Peterson, 2014).

However, the very social, interactive features that can make MOOCs so effective can also, paradoxically, facilitate the emergence of a significant amount of negativity that can, in turn, hamper the creation of a meaningful learning and teaching environment. MOOC negativity can emerge from learners on discussion forums or through peer assessment, as well as through disciplinary or institutional colleagues and from the larger public and media discourse on MOOCs. Negativity 
takes aim at many targets: a particular MOOC's subject matter, a member of the instructional staff, other learners, the instructional design of the platform, and the larger ideological, political, and economic implications of MOOCs.

Negativity has already infused ongoing conversations about MOOC pedagogy. Some MOOC faculty have shared negative experiences with teaching in the MOOC environment (Head, 2014), and negativity may be a cause of the disengaged and distant role taken by many MOOC instructors (Davidson, 2013; Ross, Sinclair, Knox, Bayne, \& Macleod, 2014). While it is rare for instructors to quit a MOOC in midstream, ${ }^{2}$ a number of instructors do not offer repeat ...the very social, interactive features iterations of their MOOCs (Freedom, that can make MOOCs so effective 2013; Head, 2013a; McGuire, 2014; can also, paradoxically, facilitate the Parry, 2013), and still more become emergence of a significant amount of disengaged from the MOOCs they are negativity that can, in turn, hamper teaching, ceasing to be active on the creation of a meaningful learning course forums and becoming solely producers of content (Comer, 2014;

Tham, 2014). While disengaged instructors have become a standard part of conversations about ex-MOOCs (Davidson, 2013; Ramesh, Goldwasser, Huang, Daumé, \& Getoor, 2014; Tomkin \& Charlevoix, 2014), it is contrary to the connectivist philosophy underpinning early MOOCs (e.g., McAuley et al., 2010), where MOOCs were designed to enable learners and instructors to co-construct a learning community (Kop, Fournier, \& Mak, 2011; Siemens, 2005). It is certainly not to the benefit of students if their instructor disconnects from the MOOC, and may contribute to the feeling of disconnection many MOOC learners experience (Rice, 2014; Warner, 2013), and the phenomenon of students eventually ceasing to participate in MOOCs or dropping out, a widely-discussed concern (e.g., Clow, 2013).

In this paper, we investigate the phenomenon of negativity in MOOCs: What are the various forms of negativity in and around MOOCs? How might negativity vary among disciplines? How does negativity impact instructors and learners in MOOCs? We examine these questions through mixed-methods research in two MOOC case studies: Denise Comer's English Composition I: Achieving Expertise (EC) (2013), Duke University and Coursera; and Ryan Baker and Elle Wang's Big Data in Education, Teachers College (2013), Columbia University and Coursera. By studying two distinct MOOCs, we can shed light on aspects of MOOC negativity that extend beyond one context and develop recommendations for how to better manage MOOC negativity to create more effective learning communities. Doing so will also enable instructors across other online educational contexts to consider MOOC pedagogy as an opportunity for the kind of "deep learning" that John Draeger (2013) notes makes the scholarship of teaching and learning so valuable and transferable.

\section{Literature Review}

MOOCs may be a new type of online learning platform, but we can understand MOOC negativity in light of prior work studying the presence and role of negative emotions and behaviors in online communities, the impact of negativity in learning and teaching, and the effects of negativity on human behavior and health.

Because MOOCs have been touted as having such disruptive potential to postsecondary education (Lenox, 2014; Wente, 2012; Whitchurch, 2012), scholarship on the impact of disruptive technologies (Christensen, 1997; Danneels,

2 However, it has happened. For example, in February 2013, Richard McKenzie left his MOOC during week 5 with the following pronouncement: "Because of disagreements over how to best conduct this course, I've agreed to disengage from it, with regret" (Kolowich, Professor leaves, 2013a). 
2004) provides one relevant lens for understanding MOOC negativity. This scholarship demonstrates that disruptive technologies often precipitate "the displacement of established [entities] by new entrants" (Gaigher, 2014, p. 264), and thereby generate a considerable amount of disagreement, anxiety, and competition.

MOOC negativity may also be understood through research about online communication. While negativity has been found in some research to account for a very small percentage (0.2 percent) of online communication (Rice \& Love, 1987), other research has found it can have a damaging effect on online communities (Chen, Wu, Srinivasan, \& Zhang, 2011; O'Sullivan \& Flanagin, 2003; Shachaf \& Hara, 2010). Some researchers have found that online interpersonal communication can be challenging due to a lack of face-to-face cues (Bazarova \& Walther, 2009; Walther, Anderson, \& Park, 1994). These conditions, along with the lack of consequences afforded by anonymity, can manifest in negative behaviors such as flaming (Walther et al., 1994; Willard, 2007) ${ }^{3}$ and trolling (Culpeper, 2010; Hardaker, 2010). ${ }^{4}$

Negativity can have a significant deleterious impact on the MOOC learning environment. Negativity can unproductively permeate the atmosphere of a MOOC's discussion forum through emotion contagion (Coviello, 2014; Kramer, Guillory, \& Hancock, 2014) and can reduce both student and instructor engagement. Research indicates that attitude has a strong correlation to learner motivation, particularly in online environments (Wen, Yang, \& Rosé, 2014), and if negativity prevails, MOOC students' motivation to engage with or complete the course will likely decline. There is some evidence that higher education faculty are particularly susceptible to burnout and that this incidence is correlated to increased complexity of teaching, such as in online environments, and to increased numbers of students (Blix, Cruise, Mitchell, \& Blix, 1994; Hogan \& McKnight, 2007; Lackritz, 2004). Instructor burnout from MOOC experiences may also impact other aspects of faculty members' professional performance, engendering unanticipated costs to their institutions and to other organizations with which the faculty members are affiliated (Halbesleben \& Buckley, 2004; Shirom, 2003).

MOOC negativity is compounded by scale: With tens of thousands of learners, there will undoubtedly be some that engage in negative behavior. Hence, negativity will be difficult to escape, even in successful courses where the majority or super-majority of learners are satisfied. Some studies have suggested that negativity has a disproportionate impact compared to its frequency (Baumeister, Bratslavsky, Finkenauer, \& Vohs, 2001; Kensinger \& Corkin, 2003). Additionally, research suggests that the impact of negativity varies considerably across individuals; thus, a particular individual's response to negativity cannot always be predicted and is not necessarily correlated to the type, degree, or quantity of negativity (Fredrickson \& Losada, 2005; Tugade \& Fredrickson, 2004). Therefore, negativity may have an outsized impact on instructors or learners, regardless of how much total negativity is seen and what proportion of behavior is negative. More broadly, negativity can disproportionately shape public, institutional, and industry perceptions about a specific MOOC, MOOCs more generally, or particular MOOC platforms. This negativity can extend to overall perceptions of particular institutions, faculty, disciplines, or about online learning writ large.

3 Flaming has been defined in a variety of ways but "can be thought of as uninhibited behavior of ... users that is revealed in the exchange of emotionally charged, hostile and insulting messages (Thompsen, 1993).

4 Hardaker defines trolling as:

A troller is a CMC user who constructs the identity of sincerely wishing to be part of the group in question, including professing, or conveying pseudo-sincere intentions, but whose real intention(s) is/are to cause disruption and/or to trigger or exacerbate conflict for the purposes of their own amusement. (2010, p. 237) 


\section{Case Study \# 1}

English Composition I (called EC below), taught by Comer and offered through Duke University in partnership with Coursera, ran from March - June 2013.5 Course enrollment began at $64,000+$ and reached 82,820 by the final week. The course provided an introduction to college-level writing. Instructional elements included four main writing projects (drafted and revised with peer feedback): didactic videos, instructor-directed and open-ended discussion forums, selfreflections conducted through open-ended questions using the platform's quiz feature, and optional Google Hangout writing workshops. Peer feedback consisted of a formative stage, where three peers provided formative feedback on drafts according to a rubric, and an evaluative stage, where four peers rated final versions on a scale of 1-6 according to a rubric.

A total of 1,289 learners earned a Statement of Accomplishment, which required a final grade of at least $70 \%$. While this rate of completion is low, it makes some sense, given that the course lasted 12 weeks and demanded rigorous, timeconsuming effort at peer review and writing, and that the instructor's approach emphasized that any effort devoted to writing, even minimal or selective engagement with the course, could be a worthwhile endeavor.

By many measures, EC yielded mostly positive outcomes. Data from a qualitative coding of EC discussion forum posts show that student attitude was 3.9 times more likely to be positive than negative, and that only $7.02 \%$ of all coded posts were negative (Comer, Clark, \& Canelas, 2014, pp. 40-41). Post-course student evaluation survey results indicated high learner satisfaction (Comer \& White, in press). Learners posted many positive comments on discussion forums ("I appreciate all the hard work ... my reviewers went to . . . thank you!"; "I am very impressed with the quality of this class, as well as with how very clearly intelligent our professor is!") ${ }^{6}$ and published positive feedback about EC in other online spaces (Franco, 2014). Several institutions have since borrowed instructional material, and Comer received the 2014 Duke University Award for Teaching with Technology, in large part due to the MOOC.

Still, the instructor perceived a high degree of negativity, resulting in instructor fatigue (Comer, 2014). Learners also perceived negativity, and this negatively impacted some learners' experiences in the course. The disconnect between evidence and impression underscores the damaging and disproportionate impact negativity can have (e.g., Baumeister et al., 2001; Kensinger \& Corkin, 2003). The sections below outline the negativity that emerged throughout the course.

\section{Negativity toward Discipline (Writing)}

Perhaps more than some other disciplines, writing can generate negativity. Learners expressed negative attitudes toward writing in numerous ways, from perceived poor writing abilities ("I'm twenty two years old and a terrible writer, from Brazil.") to a general dislike for writing ("I'm not a writer because I hate writing."). Many learners shared prior negative writing experiences: "When I enrolled in middle school, my ... teacher who was terrible, always thought what I write was terrible, that's when I started to hate writing."

\footnotetext{
${ }^{5}$ EC was funded largely through the Bill \& Melinda Gates Foundation, with additional support from Duke University and Coursera.

${ }^{6}$ EC discussion forum posts have been deidentified to preserve anonymity. Some posts have been slightly edited where necessary for grammatical correctness or clarity.
} 


\section{Negativity toward Course}

Negativity toward various aspects of the course often resulted from confusion, despite instructional staff clarifying procedures, and this negativity manifested in frustration and anger. Forum titles related to course content, such as the following, invited ongoing conversations grounded in negativity: "Seriously, this is the class?"; "Holy cow, what a verbose course!"; "I could barely read this [text] for irritation!"; "The blind leading the blind; ... (my thoughts on the peer evaluation process); "More than disappointment"). "This course ha[s] made a lot of people unhappy." Although, as stated above, our qualitative coding suggested that only $7.02 \%$ of all discussion-forum posts were negative, this negativity at scale permeated nearly all the discussion forums. Negativity toward the course tended to emerge primarily toward the following aspects:

\begin{tabular}{|c|c|}
\hline $\begin{array}{l}\text { Platform/Instructional } \\
\text { Design }\end{array}$ & $\begin{array}{l}\text { "How did you upload your essay? I can't even figure } \\
\text { [it]out...!"; } \\
\text { "My oh my am I confused and lost."; } \\
\text { "This course is a mess."; } \\
\text { "The site is hard to navigate." } \\
\text { "I was so looking forward to this course, and am enjoying } \\
\text { the lectures, but then ... it falls flat with a massive fail." } \\
\text { "I'm so angry and frustrated I could scream." }\end{array}$ \\
\hline Grading Criteria & $\begin{array}{l}\text { "I am very disappointed with my grade as well, after } \\
\text { studying so hard, and not being given a statement of } \\
\text { accomplishment. This is the only course that had very } \\
\text { strict grading policies, and I am really sorry that I } \\
\text { dedicated my precious time studying so hard for it, and } \\
\text { the only feeling that has remained is the bitter feeling, } \\
\text { nothing else." }\end{array}$ \\
\hline Readings & $\begin{array}{l}\text { "Sorry to say it, but this course is a pain in the neck. If } \\
\text { future writing assignments are somehow related to [this } \\
\text { reading] then I may drop the course. This is really stupid! } \\
\text { I feel like I am being brain washed." }\end{array}$ \\
\hline Writing Assignments & $\begin{array}{l}\text { "Am I alone in wondering why we've been set an } \\
\text { assignment to explicate a visual image ...? [S]eriously, } \\
600-800 \text { words ... This would be a worthy task for an art } \\
\text { history student - let alone for a group of budding writers." }\end{array}$ \\
\hline Lessons/Lectures & $\begin{array}{l}\text { "Tell me what you learned from Prof. Comer's lecture } \\
\text { about how to evaluate claims. How do you spot fallacious } \\
\text { thinking and respond to it according to Comer? Or } \\
\text { stylistically how can you avoid simple declarative } \\
\text { sentences that open with subject-verb? There was some } \\
\text { instruction on passive/active voice and place holder } \\
\text { subjects, but I really expected a lot more." }\end{array}$ \\
\hline
\end{tabular}

\section{Negativity toward Instructor}

Some negativity was aimed directly at the instructor. One such series of posts came from Student A: "Hi folks, I really can hardly believe what I have just seen. There is a difference between being polite and being gullible. Obviously Professor Comer uncritically buys [this reading's] self-help psychobabble. My mistake: I thought this was a course in critical thinking? Heigh ho, it is a learning experience. If this is the standard of thought of the person in charge of the course, why should I want to go on with it? Help me out here. Kind regards, [Student A]."

Another post by Student A sought to undercut the instructor's reputation and authority, while also criticizing other learners in the course: "I had assumed that the sample of participants that Prof Comer would pick for the Hangout would 
reflect the diversity of viewpoints in these forums. Instead, maybe by picking participants by lottery, what we saw was probably a perfectly representative slice of the predominantly uncritical participants in this course. Shame, it sent a message that started me checking the academic credential of Duke and Comer and thinking my time might be better spent on a Harvard, Yale or MIT MOOC."

While some peers countered Student A's posts, Student A also garnered forum fans: "I'm bothered when I read others commenting on Comer's brilliance and [Student A's] arrogance. It is actually the other way around! Where is the brilliance that constructs an instructor-centered course instead of a learner centered one? Where is brilliance when lectures from a face-to-face course are simply taped and posted as assignments with little justification for their basis or relevance? And where is brilliance when commonly understood best practices are ignored?"

\section{Negativity and Peer Interactions in Discussion Forums}

Negativity also emerged in peer-to-peer interactions in the forums: "There are too many trolls in this place." The argumentative exchange below shows Student C seemingly baiting Student B:

Student B: Out of curiosity, what exactly are the "scholarly conventions for citing sources, including in-text citations and references" that you employed? That doesn't look like any school of citation that I'm familiar with.

Student C: Dear Sir, I am not here to feed polemics. If you are familiar with other schools of citation, then please kindly show them to me. If you just have to add pressure and provoke people, you can avoid it. ... So have the best day of your life and excuse me if I don't answer anymore to any provocative comment, I have really a lot of things to do."

Student B: I think that the main problem here is that despite the fact that you say you don't want to feed polemics, you're literally creating them where there are none. I merely asked what scholarly conventions you employed. Excuse me for assuming you actually had employed any when you throw a public temper tantrum in response to someone quite neutrally saying you hadn't.

Student C: unless you cannot suggest me any official page that can help me to become better in my works, please don't write me or contact me anymore and if possible let's avoid also the red arrows, as they are quite a stupid way to express one's disappointment, according to me. I hope this time I was clear enough, please don't answer to me.

Student B: I'm still confused about your first warning? I seriously don't understand why you are so venomous towards me. ... Why [Student B], are you so angry...?

\section{Negativity and Peer Feedback}

Peer feedback was a central element of EC and included highly structured rubrics and scaffolding based on peer feedback literature (Mory, 2003; Topping, 1998; Yang, Badger, \& Yu, 2006). According to qualitative coding of peer feedback, peer feedback was generally constructive or complimentary $(97 \%)$, with only $3 \%$ being unconstructive (Comer \& Canelas, 2014, p. 3). Still, literature shows that students can be reluctant to acknowledge peers as authorities (Gielen, Peeters, Dochy, Onghena, \& Struyven, 2010; Hanrahan \& Isaacs, 2001; Strijbos, Narciss, \& Dunnebier, 2010), and this was borne out in EC.

Most negativity related to peer feedback focused on feedback towards revision that students received on drafts (termed formative feedback) rather than 
feedback for grading purposes on final versions (termed evaluative feedback): "This is ... not about scores ... [I] really wanted FEEDBACK for further improvement. I am totally shocked ... regarding feedback." Despite a course emphasis on the ways in which even providing feedback improves one's writing, some learners remained almost exclusively focused on receiving feedback and thereby expressed concerns about peers' capability to provide effective feedback: "There are many students whose first language is not English, as well as many students who are not experienced enough to comment on another's writing." Negativity also emerged in response to peer feedback received, with some learners reporting that it was contradictory ("[M]y peer feedback has been largely bewildering and contradictory."), misguided ("Some people probably do not even know how a good writing piece should look or read. I am disappointed in this peer evaluation portion of the

Because writing programs are somewhat vulnerable institutionally often being composed of contingent faculty who teach what is sometimes construed as a "service course," many in writing studies have concerns over the potential impact of MOOCs on writing programs.

class."), or rude ("[My] second peer evaluator was rude to say the least."). Even though most peer feedback was positive or constructive according to a sample of coded data, the small amount of feedback that did get coded as negative or unconstructive tended to be primarily aimed toward critiquing the writing project's main argument or focus (Comer et al., 2014): ("[A] mediocre photo from a mediocre website does not constitute good academic/scholarly writing. This is my ninth review. I have seen some compelling photos and paintings. This is not one."; "I don't waste my time with reading wikipedia articles in this course.")

\section{Negativity from Disciplinary Colleagues}

Negativity also emerged from disciplinary colleagues (writing program administrators, or WPAs, and writing faculty at other institutions). Because writing programs are somewhat vulnerable institutionally, often being composed of contingent faculty who teach what is sometimes construed as a "service course," many in writing studies have concerns over the potential impact of MOOCs on writing programs. And, although there is considerable research on how to teach writing effectively online (Gibson \& Hewett, 2009; Hewett, 2010; Hewett, 2013; Warnock, 2009), many in writing studies also have misgivings about the ability to transfer key aspects of writing pedagogy to the MOOC platform, namely the establishment of a productive community of writers and expert feedback and assessment (Krause \& Lowe, 2014). Moreover, because EC had a relatively high enrollment and was the first-ever first-year writing $\mathrm{MOOC}_{1}{ }^{7}$ it became something of a disciplinary linchpin for concerns, fears, and suspicions about MOOCs and firstyear writing instruction.

Disciplinary negativity emerged with particular intensity on the Writing Program Administrator's listserv (WPA-L) in response to a positive post stating that Comer should be commended for a strong MOOC. Over the next four days (March 20-24, 2013), a series of negative posts emerged, focused around the following areas:

7 Three other first-year writing MOOCs emerged in the months directly following EC; these were each also awarded separate funding through the Bill \& Melinda Gates Foundation: "Writing II: Rhetorical Composing" (Delagrange, S., DeWitt, S. L., Halasek, K., McCorkle, B., \& Selfe, C., 2013, Ohio State University and Coursera); "First-Year Composition 2.0" (Head, 2013b, Georgia Institute of Technology and Coursera); "Crafting an Effective Writer: Tools of the Trade" (Barkley, Blake, \& Ross, 2013, Mt. St. Jacinto Community College and Coursera). 


\begin{tabular}{|c|c|}
\hline $\begin{array}{l}\text { Negativity about } \\
\text { MOOCs' Potential } \\
\text { Impact on Higher } \\
\text { Education }\end{array}$ & $\begin{array}{l}\text { Is anyone else concerned about the practicalities of how this } \\
\text { will affect the working comditions [sic] of teachers? Of the } \\
\text { potential for more de-professionalization of education? } \\
\text { Heck, health care is too expensive. What about Massive Open } \\
\text { Online Clinics ... Instead of interacting with patients, doctors } \\
\text { can make 5-7 minute video modules on diagnosing various } \\
\text { ailments. Groups of patients can diagnose and treat each } \\
\text { other. }\end{array}$ \\
\hline $\begin{array}{l}\text { Negativity about } \\
\text { MOOCs' Potential } \\
\text { Impact on Writing } \\
\text { Programs }\end{array}$ & $\begin{array}{l}\text { [W]hether or not the folks at these institutions who are } \\
\text { experimenting with MOOCs believe these courses should have } \\
\text { bona fide college credit attached to them isn't really the issue. } \\
\text { The issue is whether... "The Powers That Be" think that these } \\
\text { courses should count for college credit ... there is very good } \\
\text { reason to be worried, vigilant, and involved in the MOOC } \\
\text { madness. } \\
\text { And what if Comer and others resist? Then some other entity- } \\
\text {-maybe a for-profit one--just says they'll do it, maybe with the } \\
\text { help of some among us who'd like the income. }\end{array}$ \\
\hline $\begin{array}{lr}\text { Negativity } & \text { about } \\
\text { MOOC } & \text { Writing } \\
\text { Pedagogy } & \end{array}$ & $\begin{array}{l}\text { The mode of teaching I've seen [in Coursera MOOCs] is right } \\
\text { out of the 19th century. It's "stand and deliver" lectures on } \\
\text { video, quizzes, and tests. There was a writing assignment in } \\
\text { [a MOOC I took] and it worked poorly ... So unless Comer and } \\
\text { [the other writing MOOC developers] are doing something } \\
\text { radically different ... these courses are DOA. } \\
\text { There's good data on how online classes like this can work; } \\
\text { there isn't good data on MOOCs, largely because they are so } \\
\text { new but also because, I am willing to guess, won't work well. } \\
\text { When I read the intro to the MOOC that welcomed me to a } \\
\text { community of } 60,000, \text { I felt immediately insignificant in such a } \\
\text { mass of students. } \\
\text { I just got a nice email [announcement] from Comer thanking } \\
\text { me for sharing my experiences and saying she is "learning so } \\
\text { much about you as writers." She also apologizes if I didn't get } \\
\text { any response from other students on my first essay. ... The } \\
\text { letter is a marvelous feat of rhetoric ... "Thanks for writing the } \\
\text { essay even though I probably haven't read it and maybe } \\
\text { nobody has." ... [T] [Tis is a writing course where feedback ... } \\
\text { is } 100 \% \text { from other students, and } 0 \% \text { from any teacher. Now } \\
\text { I'm going to write my "I am a Writer" essay, not that I have } \\
\text { that much to say. Should I make up a bunch of stuff? }\end{array}$ \\
\hline $\begin{array}{l}\text { Negativity } \\
\text { MOOC } \\
\text { Structures }\end{array}$ & $\begin{array}{l}\text { Why have MOOCs been underwritten by so much conservative } \\
\text { money? Why are huge MOOC efforts being produced by } \\
\text { private universities such as Duke? It's further to shunt the } \\
\text { poor into defunded public educational institutions and into } \\
\text { uneducational learning. The rich will continue to send their } \\
\text { offspring to private colleges, where they will continue to get } \\
\text { small classes with F2F instruction and graduate into good and } \\
\text { influential jobs. }\end{array}$ \\
\hline
\end{tabular}

Disciplinary negativity culminated with a post containing graphic sexual violence: "There's a picture going the Facebook rounds that pretty well expresses my sense of the Duke MOOC." The post contained an attachment of an image of a man starting a chainsaw aimed at his own groin and carrying the caption, "Remember that time you forgot to think?"8

8 This post, along with the attached image, is available through the WPA-L archive (https://lists.asu.edu/cgi-bin/wa?A0=WPA-L), post \#139392, 21 Mar. 2013. The 


\section{Impacts of Negativity on Instructor}

The abundance of negativity from course learners and disciplinary colleagues left the instructor by turns exhausted, frustrated, defeated, and anxious. The disciplinary negativity left her feeling largely alienated from her discipline and its members. The instructor disengaged, drastically reducing her discussion forum participation: during Weeks 1-4, Comer posted 42 times, but between weeks 5-12 Comer posted only four times, one of which was after the course ended. In other educational contexts, negativity can prompt reflection and, where needed, change and improvement to pedagogy and course design. For this instructor, facing an abundance of negativity due to the scaled nature of a MOOC, and unable to rapidly make substantive course changes in response since the course was already developed, the negativity had a substantial impact and prompted significant instructor disengagement.

\section{Case Study \#2}

In the second case study, we discuss negativity in Baker and Wang's MOOC, Big Data in Education (October - December, 2013, Columbia University), also taught through Coursera. This course had a total enrollment of over 48,000 at the termination of the course (additional students continued to enroll even after the course concluded - over 17,000 at the time of this writing). "Completion" in the course was pre-defined as earning an overall grade average of $70 \%$ or above, the grade required to receive a certificate. The overall grade was calculated by averaging the six highest grades extracted out of a total of eight assignments. For each assignment, students were allowed multiple attempts, with the exact number of attempts varying per assignment. All the assignments were automatically graded, composed of multiple-choice questions and short numerical answers. A total of 638 students completed this online course.

The production of this MOOC was coordinated between three parties: the teaching staff, the university video production team, and the course platform coordinators. The teaching staff consisted of the professor, a teaching assistant, and members from the professor's lab. Unlike some MOOCs produced in a studio with a full production team, this MOOC was recorded by the professor with a personal computer and webcam. After the recording was completed, the university production team edited the videos according to standards set by the course platform provider. Thereby, the major responsibilities of creating the course materials including the course videos, lecture slides and assignments, fell on the shoulders of the teaching staff, primarily the course instructor, leading to relatively high time and effort for the instructor.

Another unusual aspect of this course resides in direct faculty participation in the discussion forums within the course platform. Although faced with a student body of over 48,000 , the course instructor checked the discussion forums almost on a daily basis and answered a considerable number of student inquiries, posting or commenting 430 times over the 8 weeks of the course. Student reactions to the course were-as with Comer's class-largely positive, with an overall average rating at the end of the course of 2.91 on a scale of 1-4. However, there was-as with Comer's class-a subgroup of students who made negative posts towards the instructor. This was particularly frequent when the instructor attempted to directly address student concerns.

image used in the post is available through the website "We Know Memes" at the following url: http://weknowmemes.com/2013/01/remember-that-time-you-forgotto-think/ 


\section{Negativity toward Course Platform}

In the examples shown below, one student complained about features of the course and their impact on course quality, and when the instructor responded, another student responded in a negative fashion. Though this negativity was focused on the instructor, these criticisms were more relevant to the platform and the process of course creation. Lecture videos were recorded under a tight time frame with coordination among three administrative teams, making it infeasible to rapidly redo videos based on student feedback.

Instructor: "I appreciate the feedback on pauses between slides. I don't actually edit my own videos (Very few Coursera instructors do, if any), but I'll pass the feedback on to the video editors when I talk to them. More than half the class videos have already been created, though (also a standard practice on Coursera - it takes hours to make each video)."

Student H: "You might want to advise Coursera to improve on that. Coursera should do a better job in quality control when accepting courses, some of which are prepared not very well and are not flexible enough to make improvements suggested by learner feedback."

Similarly, another example shown below referred to support within the course platform; the instructor was unable in the platform to design quizzes that could accept answers by a range rather than exact answer, and received hostility from a student because of that. These posts were seen by the instructor as stressful and upsetting, making him not want to read the forums, particularly posts where the names of frequently negative students were present. Although the instructor continued to read and post to the forums, many colleagues commented that the instructor was clearly upset by the forums, and suggested that the instructor quit reading them.

Instructor: "Sorry for the confusion. It's hard to be precise about things like this. I wish there was an easy way in Coursera to set up quizzes that aren't finicky about this.

Student $H$ (same student as previous example): "According to the Honor Code for Instructors, you are supposed to either make yourself knowledgeable about Coursera's technical possibilities to define format options of answers, or to urge Coursera to provide such format options deemed necessary to be able to offer user-friendly course."

One interesting aspect of some students' negative posts was that they were not just upsetting to the instructor, they were also irritating to other students. Many negative posts received a substantial number of "down votes," a rating feature of the Coursera forum. For example, the last comment made by Student $\mathrm{H}$ in the example immediately above received multiple down votes from other students, and was in fact tied for the lowest-rating post in the entire course. This suggests that negativity is not just seen as a problem by instructors, but by other students as well. Student $\mathrm{H}$ was by far the most negative student in the course, repeatedly posting negatively, and continuing to do so even after receiving extensive public criticism from other students.

As with the previous two examples, the last comment in the example shown below also received multiple down votes from other students. Student I offered a solution to a previous student inquiry, followed by the instructor's encouragement. However, Student J expressed negativity toward the instructor's positive response in a post criticizing the video (the video had skipped a step in the process, which Student I discussed). This post by Student J was the other post tied for the lowest-rated post in the course. Again, completely redoing the video on 
short notice was not feasible with the support available for the MOOC. Even a much more extensively supported MOOC than this MOOC would find it difficult to match this student's expectations; it would essentially require full-time individuals able to drop all other tasks to immediately re-design and re-shoot videos.

Student I: (Addressed to another student's question): "You need to go through the entire import data wizard in order for the data to be imported and then the variables will appear in the drop down..."

Instructor: "[Name], good call. That's exactly correct."

Student J: "Why don't you repair the glitch in your video, @[Baker]? It matters more to us than just praising the good student."

\section{Negativity toward Instructor}

Even very small changes can be picked up by students. In a traditional classroom with a class size of around 20, it is rare to see students make public comments on a teacher's clothing style even if they do have opinions. By contrast, in the MOOC course setting, the sheer number of students almost guaranteed that any minute differences would be singled out. Therefore, the instructor in a MOOC setting is often seen under scrutiny comparable to a public figure, but without a comparable support team. Sutton and Galunic (1996) argue that the scrutiny experienced by public figures can cause distractions that undermine the quality of work via cognitive overload. Students made fun of the instructor's fashion choices and style throughout the course. While this amused rather than bothered the instructor, it did become a topic of discussion in meetings with colleagues, becoming a distraction from other, more important topics.

\section{Student G}

Baker is a dedicated teacher and even records video lectures while incarcerated. (At least it looked like an orange prison jumpsuit in the week 7 and 8 videos... I'd like to think he got into an altercation with a colleague over over-fitting a model, but it was probably due to having a sugary caffeinated drink over 16 oz on the streets of New York City...)

\section{Negativity toward Course Content}

There was also negativity towards the course goals and content, with many students without any background in the area claiming that they were the target audience and were not being served by the difficult content in the course. One example is given below. This was a surprise to the instructor; the course was designed as an upper-level graduate course and had pacing and content moderately lighter than the instructor's regular graduate course. The course was explicitly targeted to advanced students, and the course description said so. However, many students expected a course targeted at an introductory or undergraduate level, and complained about the course's pace and content. Other learners complained that the course was too slow, or insufficiently mathematical. In general, creating and supporting a course for a range of learners is a difficult challenge throughout the educational system but even more so for a MOOC that anyone can sign up for.

Student $K$

I've taken several MOOCs, and this is pretty awful so far, not because the topic is bad, or that the instructor isn't knowledgeable, but because I'm not sure professor Baker knows who he is teaching to, or for what. 
Overall, there was relatively little negativity between students in this course, and much of it involved disagreements over negative posts towards the instructor. This difference from Comer's class may be due to the relatively lower degree of required interaction between students. Most of the between-student interactions in Baker and Wang's class involved discussion of the material from a position of equality, not from a position of one student grading the other student.

\section{Disproportionate Sources of Negativity}

Among consistent forum contributors, nine participants displayed repeated negativity toward the instructor. Although these numbers represent a tiny percentage of over 48,000 registered students, they accounted for $a$ disproportionate number of negative comments. A small number of outspoken students can create a substantial negative influence on a course.

Of these nine consistently negative individuals, four also responded to a pre-course survey on their motivations (cf. Wang \& Baker, 2015). This rate of response $(44.44 \%)$ was statistically significantly higher than the rest of the class's response rate $(2.9 \%), \mathrm{X}^{2}(\mathrm{df}=1)=55.31, \mathrm{p}<0.0001$ (Wang, Paquette, \& Baker, 2014). Interestingly, all of the consistently negative students appeared to be male (according to either the pre-course survey or their choice of name on the forums).

Somewhat unexpectedly, no motivational survey items differentiated the negative students from the remainder of the class to a statistically significant degree, including survey items on academic efficacy, goal orientation, and completion confidence.

\section{Discussion}

The case studies presented here demonstrate the multifaceted nature of negativity in MOOCs and the importance of finding ways to mitigate negativity and support instructors who experience it in their courses. Significantly, much of the negativity encountered during the courses is related to elements of course design inherent in the platform or related to design choices made prior to the beginning of the course. Most of the labor and instructional time from an instructor occurs prior to a MOOC's launch, leaving the instructor with limited capability to make changes that can help address this source of negativity during the course itself. This suggests that managing negativity should be integrated into the process of course design and development-perhaps with an eye

A small number of outspoken students can create a substantial negative influence on a course.

towards creating design principles for next-generation MOOCs that reduce negativity and mitigate its effects. It is important to note that there are some positive informational aspects to negativity; it is not necessarily optimal (or possible) to eliminate negativity entirely, but it is important to reduce the degree to which it produces the instructor disengagement seen in many MOOCs.

One factor which may have increased the degree of negativity and limited the potential for response by the instructor or other course (or platform) staff was the open nature of the MOOC, where students did not have to pay money and were not attempting to obtain course credit leading toward earning a degree. Some degree of the negativity seen here may be particular to MOOCs; in a regular course, a disruptive or abusive student could ultimately be removed from the course or referred to university disciplinary authorities. In addition, the instructor's ability to assign grades in a traditional course likely restrains student negativity to some degree. Even if an instructor removed a student from a course, in an open MOOC there would be little to prevent the student from creating a new identity (a "sock puppet"), rejoining the course, and resuming the negative behavior. As such, instructors in MOOCs have considerably fewer options for dealing with negativity than instructors in for-credit online courses. 
That said, while some aspects of the design of MOOCs may amplify the problem of negativity, negativity can emerge in any discussion forum, and is a wellknown phenomenon on all types of discussion forums (Chen et al., 2011; Lee, 2005). Discussion forums have become an increasingly prominent part of for-credit online courses, and participation in these forums is strongly connected with student performance (e.g., Romero, López, Luna, \& Ventura, 2013). Similarly, instructor presence in discussion forums has been recognized as a significant factor influencing course effectiveness (Mandernach, Gonzales, \& Garrett, 2006). As such, research on how negativity emerges and how it affects instructors-particularly when it can lead to instructor disengagement-is important to pedagogical contexts beyond just MOOCs. Lessons learned from these two MOOCs can be beneficial to instructors of other online courses in managing existing and anticipated negativity. Negativity is not unique to MOOCs, but it is more prominent there, creating more opportunities to observe it, understand it, and ultimately remedy it-lessons that can be adapted to for-credit online learning contexts as well.

Based on these two case studies, we propose the following recommendations for those involved in online learning so they can better understand, manage, and respond to negativity:

Appreciate the impact of scale on negativity. While faculty are likely used to a certain amount of negativity in their own classes, whether online or faceto-face, the scaled nature of negativity in a MOOC context, with the confusion, the continual complaints (even if coming from a minority of students), and the degree of negativity expressed, can generate an impression of overwhelming, pervasive dissatisfaction-even if the majority of active students are in fact satisfied. This is likely to be part of why negativity can have a disproportionate impact. Even in nonMOOC learning contexts, the aggregated impact of negativity over time or alongside other negativity a person might be concurrently experiencing (even if unrelated to the course itself) might yield a similar perception of scale and thereby contribute to the outsized impact negativity can have on instructors and learners.

Prepare instructional and development teams for negativity in discussion forums. There will be negativity in the forums, and there are likely to be several individuals in each MOOC who engage in forms of trolling or flaming (Student $\mathrm{H}$ from case study 2 in fact boasted on the forum of having brought his unique perspective to several MOOCs.). Completely eliminating negativity is probably infeasible, and it is impossible to avoid entirely since negativity can appear suddenly in previously positive threads. As discussed above, it is not feasible to remove negative individuals from a MOOC completely; they can simply create a new "sock puppet" identity and re-register. Still, there may be approaches to reducing negativity and mitigating its impacts. One option would be to place problematic individuals in a sub-community within the course, as happens in online gaming with negative or abusive individuals. In this situation, these individuals are only allowed to interact with other negative or abusive individuals, and the instructor and other students do not receive their posts. Another option involves MOOC providers dedicating staff time to visit forums and take responsibility for platform limitations, or even defend instructors when appropriate. This has the potential to create a shared community experience and some measure of solidarity, which may reduce negativity's impact on instructors. The experience of solidarity may be more important than simply defending the instructor.

Understand what contextual factors might make some learners more prone to negativity. MOOCs remain a new experience in many ways, for learners and instructors. Many MOOC learners are unfamiliar with the platform, online learning, and perhaps with higher education and discipline-specific knowledge. Some may be what David Mathew (2014) terms a "Fragile Learner": one who is struggling, anxious, inclined to quit, and less motivated than other 
learners. Moreover, MOOCs create an intercultural environment; within intercultural environments, the nuances of interaction, especially in an online platform, can be tricky, leading to negativity or the appearance of negativity. This context suggests that instructional teams should anticipate negativity by integrating supporting strategies and resources well in advance rather than addressing problems as they arise. Resources should therefore be integrated as part of mandatory course content rather than on an as-needed, participant demand basis. Since many MOOCs rely on peer assessment, which can elicit negativity, it may be useful to educate learners on the value of peer feedback by introducing them to research attesting to its value and by providing instructional content designed to help writers learn how to make productive use of feedback (even contradictory feedback) (Bangert-Drowns, Kulik, Kulik, \& Morgan, 1991).

Prepare instructional and development teams for negativity from disciplinary colleagues. Colleagues in disciplines may evidence negativity toward MOOCs. Some of this discipline-based negativity may involve concerns unique to a particular discipline, as in the case of writing pedagogy, or it may involve concerns about MOOCs and higher education more broadly. Since MOOCs at this point pose, or at least provide a sense of, a disruption to higher education, and since members of MOOC instructional teams occupy a visible presence within this disruption, those involved with teaching MOOCs should be prepared to experience disciplinary-based negativity from colleagues, and should be prepared to engage in productive conversations with colleagues about the history, implications, promises, and challenges of MOOCs in general. More broadly, those involved with other potentially disruptive innovations in higher education, online learning, and educational technology might also anticipate and prepare for negativity from disciplinary colleagues.

Create open spaces for the exchange of experiences with negativity. Sharing specific experiences with negativity such as these, and the lessons learned, can help develop support for instructors and adjust their expectations, mitigating the impact of negativity. Doing so enables those who experience negativity to reframe their perceptions of it, and enables others to learn from these experiences, and adapt or otherwise modify their own approaches to negativity. Creating open, ongoing discussions about negativity-in MOOCs and in other online educational contexts-also recognizes that the impact of negativity on instructors and learners is highly variable and cannot always be fully anticipated, reinforcing the idea that opportunities for sharing need to be ongoing.

Search for learning opportunities in negativity. Some instances of negativity are best seen as learning moments, where instructional staff can emphasize what is or is not constructive criticism, explore the complexities of intercultural communication, and highlight the value of civic disagreement and debate in academic contexts. In addition, negativity is often combined with input by instructors and the developers of platforms, which can and should be distilled to improve future iterations of the course.

\section{Conclusion}

Negativity is a challenge and a problem for online learning environments such as MOOCs. While its full causes and impacts are not yet known, it appears to negatively impact instructors, in some cases out of proportion with its overall frequency of occurrence. In this paper, we present two case studies on negativity in MOOCs, and discuss ways to better support instructional and development teams in anticipating and responding to negativity. As such, it is underscored that anticipating negativity well in advance would avail instructors to better develop practices and mitigate negative impact on both instructors and students. Developing practices that respond more effectively to negativity will benefit many 
involved with MOOCs, including faculty members who are about to start teaching on MOOC platforms, especially as more institutions are adopting the MOOC as a teaching platform (Shah, 2014). By reducing the problematic impacts of negativity, we can better maintain instructor and student engagement, potentially leading in the long term to greater satisfaction with the MOOC experience for both instructors and learners, and thereby move toward improving retention and outcomes for both of these groups. Furthermore, the lessons learned from MOOC negativity can also benefit instructors and learners in for-credit online learning contexts as they seek to understand, respond to, and manage negativity as a means of strengthening online instructional experiences and outcomes.

\section{References}

Baker, R., \& Wang, Y. (2013). Big data in education. Retrieved from https://www.coursera.org/course/bigdat a-edu

Bangert-Drowns, R., Kulik, C. L. C., Kulik, J. A., \& Morgan, M. (1991). The instructional effect of feedback in testlike events. Review of Educational Research, 61(2), 213-238. doi:10.2307/1170535

Barkley, L., Blake, T., \& Ross, L. (2013). Crafting an effective writer: Tools of the trade (fundamental English writing). Retrieved from https://www.coursera.org/course/basicw riting

Baumeister, R. F., Bratslavsky, E., Finkenauer, C., \& Vohs, K. D. (2001). Bad is stronger than good. Review of General Psychology, 5(4), 323-370. doi: $10.1037 / / 1089-2680.5 .4 .323$

Bazarova, N. N., \& Walther, J. B. (2009). Attribution of blame in distributed groups. In P. Lutgen-Sandvik \& B. Davenport Sypher (Eds.), The destructive side of organizational communication: Processes, consequences, and constructive ways of organizing (pp. 252-266). Mahwah, NJ: Routledge.

Blix, A. G., Cruise, R. J., Mitchell, B. N., \& Blix, G. G. (1994). Occupational stress among university teachers. Educational Research, 36(2), 157-169. doi:10.1080/0013188940360205
Brinton, C. G., Chiang, M., Jain, S., Lam, H., Liu, Z., \& Wong, F. M. F. (2013). Learning about social learning in MOOCS: From statistical analysis to generative model. IEEE Transactions on Learning Technologies, 7(4), 346-359. doi:10.1109/TLT.2014.2337900

Carver, L., \& Harrison, L. M. (2013). MOOCs and democratic education. Liberal Education, 99(4), 20+. Retrieved from

http://go.galegroup.com.proxy.lib.duke. edu/ps/i.do?id=GALE\%7CA352376676\& $v=2.1 \& u=$ duke perkins\&it $=r \& p=A O N E \&$ $\mathrm{sw}=\mathrm{w} \& \mathrm{asid}=199095321 \mathrm{a} 497 \mathrm{~d} 7 \mathrm{aa} 573 \mathrm{fa}$ $84500 f d 32 b$

Chen, C., Wu, K., Srinivasan, V., \& Zhang, X. (2011). Battling the Internet water army: Detection of hidden paid posters. arXiv:1111.4297. Retrieved from http://arxiv.org/abs/1111.4297

Cheng, C. K., Paré, D. E., Collimore, L. M., \& Joordens, S. (2011). Assessing the effectiveness of a voluntary online discussion forum on improving students' course performance. Computers \& Education, 56(1), 253-261. doi: $10.1016 /$ j.compedu.2010.07.024

Christensen, C. M. (1997). The innovator's dilemma: When new technologies cause great firms to fail. Boston, MA: Harvard Business School Press. 
Clow, D. (2013, April 10). MOOCs and the funnel of participation. In $D$. Suthers (Ed.). LAK 2013: Third international conference on learning analytics and knowledge: 8-12 April 2013. Paper presented at The Third Conference on Learning Analytics and Knowledge (LAK 2013), Leuven, Belgium, 8-12 April (pp.185-189). New York, NY: ACM. doi:10.1145/2460296.2460332

Comer, D. (2013). English Composition I: Achieving Expertise. Retrieved from https://class.coursera.org/composition001

Comer, D. (2013, November 11). Five tips for learning online. Retrieved from https://www.youtube.com/watch?v=pjDQ RgtbIVE

Comer, D. (2014). Learning how to teach ... differently: Extracts from a MOOC instructor's journal. In S. Krause \& C. Lowe (Eds.), Invasion of the MOOCs. The promise and perils of massive open online courses (pp. 130-149). Anderson, SC: Parlor Press, 2014.

Comer, D., Clark, C., \& Canelas, D. (2014). Writing to learn and learning to write across the disciplines: Peer-to-peer writing in introductory-level MOOCs. IRRODL, 15(5), 26-82. Retrieved from http://www.irrodl.org/index.php/irrodl/art icle/view/1850

Comer, D., \& Canelas, D. (2014). MOOC research initiative final report. Retrieved from

http://www.moocresearch.com/reports

Comer, D., \& White, E. M. (in press). Adventuring into MOOC writing assessment: Challenges, results, and possibilities. College Composition and Communication.

Coviello, L., Sohn, Y, Kramer, A. D, Marlow, C., Franceschetti, M., Christakis, N. A., \& Fowler, J. H. (2014). Detecting emotional contagion in massive social networks. PloS ONE, 9(3), 1-6. doi:10.1371/journal.pone.0090315

Culpeper, J. (2010). Impoliteness: Using language to cause offence. Cambridge, England: Cambridge University Press.
Daniel, J. (2012). Making sense of MOOCs: Musings in a maze of myth, paradox and possibility. Journal of Interactive Media in Education, 2012(3). doi:10.5334/201218

Danneels, E. (2004). Disruptive technology reconsidered: A critique and research agenda. Journal of Product Innovation Management, 21(4), 24658. doi:10.1111/j.0737-

6782.2004.00076.x

Davidson, C. (2013, April 29). Peer learning, online learning, MOOCs, and me: Response to The Chronicle of Higher Education. Retrieved from http://www.hastac.org/blogs/cathydavidson/2013/04/29/peer-learningonline-learning-moocs-and-meresponse-chronicle-higher

Delagrange, S., DeWitt, S. L., Halasek, K., McCorkle, B., \& Selfe, C. (2013). Writing II: Rhetorical composing. Retrieved from https://www.coursera.org/course/writin g2

Draeger, J. (2013). Why bother with the scholarship of teaching and learning? InSight, 8, 12-19.

Franco, R. T. (2014). What is Moocstream? Retrieved from http://moocstream.blogspot.com/2014 /03/what-is-

moocstream.html\#.U7D14KuG1y8

Freedom, D. (2013, September 11). MOOC, learn, repeat? Retrieved from http://degreeoffreedom.org/mooc-

learn-repeat/

Fredrickson, B. L., \& Losada, M. F. (2005). Positive affect and the complex dynamics of human flourishing. American Psychologist, 60(7), 678-686. doi:10.1037/0003-066X.60.7.678

Gaigher, S. (2014). The predictive value of disruptive technology theory for digital publishing in the traditional publishing environment: A South African case study. Journal of Scholarly Publishing, 45(3), 261-288. doi: $10.1353 / \mathrm{scp} .2014 .0010$ 
Gibson, K., \& Hewett, B. (Eds.). (2009). Annotated bibliography CCCC committee for best practices in online writing instruction. Retrieved from http://www.ncte.org/library/NCTEFiles/G roups/CCCC/Committees/OWIAnnotated Bib.pdf

Head, K. (2013a). First-year composition 2.0. Retrieved from https://www.coursera.org/course/gtcom $\mathrm{p}$

Head, K. (2013b). Lessons learned from a freshman composition MOOC. The Chronicle of Higher Education. Retrieved from

http://chronicle.com/blogs/wiredcampus /lessons-learned-from-a-freshmancomposition-mooc/46337

Head, K. (2014). The hidden costs of MOOCs. In S. Krause \& C. Lowe (Eds.), Invasion of the MOOCs. The promise and perils of Massive Open Online Courses (pp. 45-55). Anderson, SC: Parlor Press.

Hewett, B. (2010). The online writing conference: A guide for teachers and tutors. Portsmouth, NH: Heinemann.

Hewett, B. (2013). Initial report of the CCCC committee for best practice in online writing instruction (OWI). The state-of-the-art of OWI. Retrieved from http://www.ncte.org/library/NCTEFiles/G roups/CCCC/Committees/OWI_State-ofArt_Report_April_2011.pdf

Hogan, R. L., \& McKnight, M. A. (2007). Exploring burnout among university online instructors: An initial investigation. The Internet and Higher Education, 10(2), 117-124. doi:10.1016/j.ineduc.2007.03.001

Hollands, F. M., \& Tirthali, D. (2014). MOOCs: Expectations and reality. Full report.

Center for Benefit-Cost Studies of Education, Teachers College, Columbia University,

NY. Retrieved from

http://cbcse.org/wordpress/wpcontent/u ploads/2014/05/MOOCs_Expectations_a nd_Reality.pdf
Jordan, K. (2013). MOOC completion rates: The data. In katy.jordan.com. Retrieved from http://www.katyjordan.com/MOOCproje ct.html

Kanuka, H. (2010, May 17). Culturally diverse communication through communication technologies: A Canadian viewpoint. In Z. Abas, I. Jung, \& J. Luca (Eds.), Proceedings of Global Learn 2010. Paper presented at Global Learn Asia Pacific 2010: Global Conference on Learning and Technology, Penang, Malaysia (pp. 3798-3803). Chesapeake, VA: Association for the Advancement of Computing in Education. Retrieved from http://www.editlib.org/p/34474

Kensinger, E. A., \& Corkin, S. (2003). Effect of negative emotional content on working memory and long-term memory. Emotion, 3(4), 378-393. doi:10.1037/1528-3542.3.4.378

Kolowich, S. (2013a). Professor leaves a MOOC in mid-course in dispute over teaching. The Chronicle of Higher Education. Retrieved from http://chronicle.com/blogs/wiredcampus /professor-leaves-a-mooc-in-midcourse-in-dispute-over-teaching/42381

Kolowich, S. (2013b). The professors who make the MOOCs. The Chronicle of Higher Education, 59(28), pp. A20-A23.

Kop, R., Fournier, H., \& Mak, J. S. F. (2011). A pedagogy of abundance or a pedagogy to support human beings? Participant support on Massive Open Online Courses. The International Review of Research in Open and Distance Learning, 12(7), 74-93. Retrieved from http://www.irrodl.org/index.php/irrodl/a rticle/view/1041 
Kouzmanoff, A. (2014). An interview with Professor Michael Goldberg, instructor of "Beyond

Silicon Valley: Growing entrepreneurship in transitioning economies." Retrieved from

http://press.coursetalk.com/post/88663

459155/an-interview-with-professormichael-goldberg

Kramer, A. D., Guillory, J. E., \& Hancock, J. T. (2014). Experimental evidence of massive-scale emotional contagion through social networks. Proceedings of the National Academy of Sciences of the United States of America, 111(24), 8788-8790. doi:10.1073/pmas.1320040111.

Krause, S. D., \& Lowe, C. (Eds.). (2014). Invasion of the MOOCs: The promises and perils of Massive Open Online Courses. Anderson, SC: Parlor Press.

Lackritz, J. R. (2004). Exploring burnout among university faculty: Incidence, performance, and demographic issues. Teaching and Teacher Education, 20(1), 713-729.

doi: $10.1016 /$ j.tate.2004.07.002

Lee, H. (2005). Behavioral strategies for dealing with flaming in an online forum. The Sociological Quarterly, 46(2), 385403. 8525.2005.00017.x doi:10.1111/j.1533-

Lenox, M. (2014, January 9). 'More' not 'or': Fear and loathing the world of MOOCs. Forbes. Retrieved from http://www.forbes.com/sites/darden/20 14/01/09/more-not-or-fear-andloathing-the-world-of-moocs/

Mandernach, B. J., Gonzales, R. M., \& Garrett, A. L. (2006). An examination of online instructor presence via threaded discussion participation. Journal of Online Learning and Teaching, 2(4), 248-260.

Mathew, D. (2014). The internet is unwell ... and will not be at school today: Oppositions, omissions and online anxiety. InSight, 9, 9-27.
McGuire, R. (2014). The best MOOC provider: A review of Coursera, Udacity, and Edx. Retrieved from http://www.skilledup.com/articles/thebest-mooc-provider-a-review-ofcoursera-udacity-and-edx/

McAuley, A., Stewart, B., Siemens, G., \& Cormier, D. (2010). The MOOC model for digital practice. Retrieved from www.elearnspace.org

Mory, E. H. (2003). Feedback research revisited. In J. $\mathrm{H}$. Jonassen (Ed.). Handbook of research on educational communications and technology ( $\mathrm{pp}$. 745-783). New York, NY: MacMillan Library Reference.

O'Sullivan, P., \& Flanagin, A. (2003). Reconceptualizing "flaming" and other problematic messages. New Media \& Society, 5(1) 69-94. doi: $10.1177 / 1461444803005001908$

Parr, C. (2013, May 9). MOOC completion rates 'below 7\%'. Times Higher Education. Retrieved from http://www.timeshighereducation.co.uk/ news/mooc-completion-rates-below7/2003710.article

Parry, M. (2013, September 3). A star MOOC professor defects-at least for now. The Chronicle of Higher Education. Retrieved from http://chronicle.com/article/A-MOOCStar-Defects-at-Least/141331/

Peterson, R. (2014). MOOC fizzles. Academic Questions, 27(3), 316-319. doi: $10.1007 / \mathrm{s} 12129-014-9434-3$

Ramesh, A., Goldwasser, D., Huang, B., Daumé, H., \& Getoor, L. (2014) Uncovering hidden engagement patterns for predicting learner performance in MOOCs. Retrieved from http://www.umiacs.umd.edu/ hal/docs/ daume14moocengagement.pdf

Rice, R. E., \& Love, G. (1987). Electronic emotion socioemotional content in a computer-mediated communication network. Communication research, 14(1), 85-108. doi: $10.1177 / 009365087014001005$ 
Romero, C., López, M. I., Luna, J. M., \& Ventura, S. (2013). Predicting students' final performance from participation in on-line discussion forums. Computers \& Education, 68, 458-472. doi:10.1016/j.compedu.2013.06.009

Ross, J., Sinclair, C. Knox, J. Bayne, S., \& Macleod, H. (2014). Teacher experiences and academic integrity: The missing components of MOOC pedagogy. MERLOT Journal of Online Learning and Teaching, 10(1), 57-69. Retrieved from http://jolt.merlot.org/vol10no1/ross_031 4.pdf

Shachaf, P., and Hara, N. (2012). Beyond vandalism: Wikipedia trolls. Journal of Information Science, 36(3), 357-370. doi: $10.1177 / 0165551510365390$

Shah, D. (2014). MOOCs in 2014: Breaking down the numbers. EdSurge.com. Retrieved from: https://www.edsurge.com/n/2014-12-26moocs-in-2014-breaking-down-thenumbers

Shirom, A. (2003). Job-related burnout: A review. In J. C. Quick \& L. E. Tetrick (Eds.), Handbook of occupational health psychology (pp. 245-264). Washington, DC: American Psychological Association.

Siemens, G. (2005). Connectivism: A learning theory for the digital age. International Journal of Instructional Technology and Distance Learning, 2(1), 3-10. Retrieved from http://www.itdl.org/Journal/Jan_05/articl e01.htm

Strijbos, J. W., Narciss, S., \& Dunnebier, K. (2010). Peer feedback content and sender's competence level in academic writing revision tasks: Are they critical for feedback perceptions and efficiency? Learning and Instruction, 20(4), 291-303. doi:10.1016/j.learninstruc.2009.08.008 Sutton, R. I., \& Galunic, D. C. (1996). Consequences of public scrutiny for leaders and their organizations. In L. L. Cummings \& B. M. Staw (Eds.), Research in organizational behavior, 18, (pp. 201250). Greenwich, CT: JAI Press.
Tham, J. (2014). C.08 "MOOCing back to school: A roundtable of professors as students in massive open online courses." Retrieved from http://praxis.technorhetoric.net/tikiindex.php?page $=$ CCCC2014_C08

Thompsen, P. A. (1993, February). A social influence model of flaming in computer-mediated communication. Paper presented at the Annual Meeting of the Western States Communication Association, Albuquerque, NM. Retrieved from https://archive.org/stream/ERIC_ED35 5572/ERIC_ED355572_djvu.txt

Tomkin, J. H., \& Charlevoix, D. (2014). Do professors matter?: Using an $\mathrm{a} / \mathrm{b}$ test to evaluate the impact of instructor involvement on MOOC student outcomes. Proceedings of the first ACM conference on Learning @ scale conference. Paper presented at the Learning @ scale conference, Atlanta, GA (pp. 71-78). doi:10.1145/2556325.2566245

Topping, K. (1998). Peer assessment between students in colleges and universities. Review of Educational Research, 68(3), 249-276. doi: $10.3102 / 00346543068003249$

Tugade, M. M., \& Fredrickson, B. L. (2004). Resilient individuals use positive emotions to bounce back from negative emotional experiences. Journal of Personality and Social Psychology, 86(2), 320-333. doi: $10.1037 / 0022-3514.86 .2 .320$

Vygotsky. L. S. (1978). Mind in society: The development of higher psychological processes. Cambridge, MA: Harvard University Press.

Walther J. B., Anderson J. F., \& Park D. W. (1994). Interpersonal effects in computer-mediated interaction: A meta-analysis of social and antisocial communication. Communication Research, 21(4), 460487. doi: $10.1177 / 00936509402100400$ 2 
Wang, Y., \& Baker, R. (2015). Content or platform: Why do students complete MOOCs? MERLOT Journal of Online Learning and Teaching, 11(1), 191-218. Wang, Y., Paquette, L., Baker, R. (2014) A longitudinal study on learner career advancement in MOOCs. Journal of Learning Analytics, 1(3), 203-206.

Warner, J. (2013, April 22). I'm failing my MOOC. Inside Higher Ed. Retrieved from

http://www.insidehighered.com/blogs/ju st-visiting/im-failing-my-mooc

Warnock, S. (2009). Teaching writing online: How and why. Urbana, IL: National Council of Teachers of English.

Weissmann, J. (2013, September 8). There's something very exciting going on here. The Atlantic. Retrieved from http://www.theatlantic.com/business/ar chive/2012/09/theres-something-veryexciting-going-on-here/262119/

Wen, M., Yang, D., \& Rosé, C. P. (2014). Sentiment analysis in MOOC discussion forums: What does it tell us? Proceedings of educational data mining. Retrieved from http://www.cs.cmu.edu/ mwen/papers/ icwsm2014-camera-ready.pdf
Wente, M. (2012, February 4). We're ripe for a great disruption in higher education. The Globe and Mail. Retrieved from http://www.theglobeandmail.com/comm entary/were-ripe-for-a-great-disruptioninhigher-education/article543479/

Whitchurch, C. (2012). Expanding the parameters of academia. Higher Education, 64(1), 99-117. doi: $10.1007 /$ s10734-011-9483-2

Willard, N. E. (2007). Cyber-bullying and cyber-threats responding to the challenge of online social aggression, threats, and distress. Champaign, IL: Research Press.

Yang, M., Badger, R., \& Yu, Z. (2006). A comparative study of peer and teacher feedback in a Chinese EFL writing class. Journal of Second Language Writing, 15(3), 179-200. 
Appendix

EC Forum Data Coded in March 2014

\begin{tabular}{|l|l|}
\hline Data Type & Source Coded \\
\hline Week 1 Discussion Forum & 36 Full Threads, 106 Posts \\
\hline Week 2 Discussion Forum & 35 Full Threads, 289 Posts \\
\hline Week 3 Discussion Forum & 27 Full Threads, 169 Posts \\
\hline Week 4 Discussion Forum & 35 Full Threads, 204 Posts \\
\hline General Discussion Forum & 86 Posts \\
\hline $\begin{array}{l}\text { Top Three Reputation Posters in Discussion } \\
\text { Forums: }\end{array}$ & 209 Posts \\
o Student D (539 total posts) & \\
o Student E (306 total posts) & \\
o Student F (21 total posts) & \\
\hline $\begin{array}{l}\text { Peer responses to "I Am A Writer," a 300- } \\
\text { word introductory discussion forum post. } \\
\text { (Total posts: } 8000 \text { ) }\end{array}$ \\
\hline $\begin{array}{l}\text { Peer feedback on major writing projects, only } \\
\text { the open-ended questions (Total peer } \\
\text { feedbacks: } 14,682 \text { ): }\end{array}$ & 342 peer feedbacks provided by 50 \\
\hline $\begin{array}{l}\text { Final Reflective Essays, only comments about } \\
\text { providing and receiving peer feedback. (Total } \\
\text { Final Reflective Essays Submitted: 1415). }\end{array}$ & \\
\hline
\end{tabular}


Denise Comer is Assistant Professor of the Practice, Writing Studies, and Director, First-Year Writing, at Duke University. She earned her PhD in English Literature and Composition and Rhetoric from the University of South Carolina. She teaches writing seminars and a writing MOOC, English Composition I: Achieving Expertise. Her MOOC scholarship has appeared in IRRODL, Invasion of the MOOCs (Utah State, 2014), and (forthcoming, co-authored with E. M. White) College Composition and Communication. Her research explores writing pedagogy and writing program administration. She has authored It's Just a Dissertation: The Irreverent Guide to Transforming Your Dissertation from Daunting to Doable to Done (Fountainhead, 2014; co-authored with B.G. Garrett); Writing in Transit (Fountainhead, 2015); and Writing for Success in College and Beyond (Connect for Education, 2015).

Ryan Baker is Associate Professor of Cognitive Studies at Teachers College, Columbia University, and Program Coordinator of TC's Masters of Learning Analytics. He earned his PhD in Human-Computer Interaction from Carnegie Mellon University. Dr. Baker was previously Assistant Professor of Psychology and the Learning Sciences at Worcester Polytechnic Institute, and served as the first technical director of the Pittsburgh Science of Learning Center DataShop, the largest public repository for data on the interaction between learners and educational software. He is currently serving as the founding president of the International Educational Data Mining Society, and as associate editor of the Journal of Educational Data Mining. He has taught two MOOCs, Big Data and Education, and Data, Analytics, and Learning. His research combines educational data mining and quantitative field observation methods to better understand how students respond to educational software, and how these responses impact their learning. He studies these issues within intelligent tutors, simulations, multi-user virtual environments, MOOCs, and educational games.

Yuan "Elle" Wang is Doctoral Research Fellow in Cognitive and Learning Sciences in Department of Human Development at Teachers College, Columbia University. She received her MA in Communication, Technology, and Education in Department of Mathematics, Sciences, and Technology in the same institution. She has previously published in peer reviewed, scientific journals such as Journal of Learning Analytics and MERLOT Journal of Online Learning and Teaching. 